Western New England University School of Law

Digital Commons @ Western New England University School of Law

Faculty Scholarship

Faculty Publications

2013

\title{
Becoming Director: An Internal Candidate's View
}

Pat Newcombe

Western New England University School of Law, pnewcombe@law.wne.edu

James M. Donovan

University of Kentucky College of Law Library

Follow this and additional works at: http://digitalcommons.law.wne.edu/facschol

Part of the Library and Information Science Commons

\section{Recommended Citation}

Pat Newcombe and James M. Donovan, Becoming Director: An Internal Candidate's View, 34 LIBRARY MANAGEMENT 188 (2013).

This Article is brought to you for free and open access by the Faculty Publications at Digital Commons @ Western New England University School of Law. It has been accepted for inclusion in Faculty Scholarship by an authorized administrator of Digital Commons @ Western New England University

School of Law. For more information, please contact pnewcombe@law.wne.edu. 


\section{Becoming Director: An Internal Candidate's View}

\section{Patricia A. Newcombe and James M. Donovan}

Articles reviewing the challenges of assuming a library directorship typically begin in the middle of the story. The new hire arrives from another campus to face a range of challenges. The accounts from there go on to extract a general map of the initial experiences along with helpful tools to navigate this intimidating terrain. That view, we suggest, obscures natural fault lines within the community of new directors. These divisions can fundamentally influence the initial experiences upon which the authors are offering their advice.

On such variable concerns the route by which the successful applicant has been named the new director. Some are in-house candidates with specific experience in the library they will now lead, while others are outside candidates who face the added challenge to understand the ways that their understanding of other institutions will translate to the new context. The latter is so much the more common that it is often taken for granted. Michelle Wu and Charles J. Ten Brink, for example, draft a solid sketch of the interview process in these terms, ${ }^{1}$ and while Barbara Dewey recognizes the potential impact of the divergent paths, she is able to consider the unique issues of the internal candidate for only a single paragraph. ${ }^{2}$ On the contrary, we suggest that this distinction impacts not only the early actions of the new director, but the hiring process as well.

To bring greater balance to the literature of director hiring, we offer the personal experience of the lead author as a successful internal candidate, and put this personal account into the broader context of the hiring process for library leadership positions.

\section{Rise of the Interim Director}

It is a bit disturbing to learn that your library's leader is leaving. We were understandably unsure how this might impact the workplace where we all spent so much of our time. The immediate worry concerned the interregnum and the appointment of the interim Director. Who would the Dean choose for that role, and how involved would this person expect to be in the day-to-day running of the library? Would this person understand the operations and priorities of our library? Would he or she view the role of interim as caretaker until the permanent Director is chosen, or as activist to make sweeping changes within this short window?

In even the best of circumstances, until these details are settled the staff will experience a period of exaggerated speculation and uncertainty. Prolonging this period for us, our

\footnotetext{
${ }^{1}$ Michelle Wu \& Charles J. Ten Brink, Rebuilding the Profession: Recommendations for Librarians Interested in Becoming Academic Law Library Directors: Stalking a Law Library Directorship, 99 Law Library Journal 124 (2007).

2 Barbara I. Dewey, "In Transition: The Special Nature of Leadership Change," 52 Journal of Library Administration 133-144, 141 (2012).
} 
Director had announced her departure six months ahead of time, giving everyone plenty of time to begin the worrying.

A month before our Director left, the Dean announced that one of the nonlibrarian faculty members would take over as interim Director while the school conducted a national search for a permanent replacement. This appointment answered at least some of our questions. While a librarian would have seemed a natural choice, at least this faculty member had been a regular library user and easy to work with. Any lingering fears were allayed by his assurances that he planned to be very hands-off in his oversight of the library. He would be available for consultation, but would leave the routine management in my hands as Associate Director.

Because I was Associate Director, many perhaps expected that I would be the natural choice to step into this leadership role. While I was not privy to the Dean's thinking on this point, I did believe that there were definitive benefits to not being appointed as the interim. Under the new arrangement my workload increased quite a bit, but the experience of taking on this work was invaluable and gave me a good feel for what it might be like to actually lead the library. I was, in other words, free to continue my own work and take on most of the responsibilities of the Director without feeling "on trial" should I decide to toss my name into the hat.

For the short term, there were practical benefits to the library to have a podium faculty member in this temporary position. We needed to make some hard decisions about canceling many of our print state statutes and much of our print law review collection. It fell to the interim Director to bring these issues to the faculty. Changing the availability of print resources that our faculty had been accustomed to have physically in the library can be an unpleasant transition. That the spokesperson proposing these changes was one of their own proved to be a great help. In the end, we decided to cancel forty state statute sets and hundreds of print law review titles for available on HeinOnline without embargo. I realized that were there to be any resentment raised by these sizeable changes, it might have been a disadvantage as an internal candidate to have been the one to push to upend their comfortable patterns.

This process was but one that made me realize that it can be extremely awkward for an interim to become a candidate for the permanent position. A tension could easily arise between doing what the library needed, and doing what would make me look good to the search committee. If the interim director is viewed as 'trying out' the Director's position, the rationale behind her decisions, as well as her forthrightness, would certainly fall under scrutiny.

Colleagues within and outside of the institution commiserated about the presumed slight at not having been named interim Director. All things considered, though, I decided to look positively on the fact that if there was a national search through which I received the position, that this process would be a strong endorsement. Perhaps I lean too much toward the "sunny side" of life, but this was sincerely my viewpoint when I accepted my role as managing the library without the title of interim. 
Pat's story raises a number of interesting issues on interim Directors. ${ }^{3}$ Writers can be divided as to whether a member who "loved books and libraries...could administer one temporarily." The appropriateness of the choice may relate to the kinds of actions the interim anticipates. One repeated suggestion is that the interim should have a short, but definite list of one to three goals to be achieved during the term. ${ }^{5}$ Commonsense suggests that in such circumstances the goals should play to the interim's strengths: If you can only do a few things in a short time, choose those things that need doing that you know you could do well.

While the nonlibrarian interim may have difficulty thinking of such goals in the strictly librarian vein, he or she should remember they bring a unique perspective to the academic library that can profitably benefit the institution. Too often librarians go about their business with only a vague and idealized understanding of how many in their primary patron groups, especially faculty, actually use the library. Having a faculty member function as interim, then, can provide a rare opportunity to glean valuable perspective on, and improve services for, this category of users. Taking full advantage of that kind of expertise could easily fill the months an interim is likely to be at the helm.

Pat's intuition that interims should not be candidates for the permanent position also receives support in the literature, ${ }^{6}$ and for much the same reasons she states, that in such situations "no action taken during the acting director's period of administration can be distinguished from an electioneering gambit."7 This rule, however, is far from uniform across the profession. ${ }^{8}$

One unusual aspect of this account is the use of the interim to push through controversial changes. Incoming directors might wish this were more common

\footnotetext{
${ }^{3}$ Some have tried to carve out a distinction between "acting" and "interim" in the present context. For example, "The term interim implies regular responsibilities during a specified period and is to be preferred over the term acting, which is commonly seen as less-than-regular leadership on an interim basis." John E. Chapman, Judy J. Chapman, \& John O. Lostetter, "The Acting or Interim Leadership Position:

Expectations, Perceptions, Realities," 13(4) Health Care Management Review 81-88, 84 (1988). The distinction is whether one actually acts "as" the leader for the duration (the interim), or "like" a leader (the acting). Although this view offers an interesting and potentially fruitful distinction, it falls outside our present discussion and thus we shall use the two terms interchangeably.

${ }^{4}$ Joanne R. Euster \& Eric Solomon, "In Praise of Acting and Permanent Library Directors and Their Symbiosis: A Dialogue," 43(1) Library Trends 136-143 (1994).

${ }_{5}^{5}$ Paul J. Kobulnicky, "Between the Acts: The Interim or Acting Director of a Research Library," 24(3) Journal of Library Administration 3-29, 21 (1997); Euster and Solomon at 143.

${ }^{6}$ E.g., Sandra F. Weingart, "Costs and Benefits of Interim Managerial Assignments in an Academic Library," 24 Library Management 237-242, 240 (2003).

${ }^{7}$ Euster and Solomon at 143; see also Norm Medeiros, "Training Ground: The Role of Interim Library Director," 26(3) OCLC Systems \& Services 153-155, 154 (2010).

${ }^{8}$ Gail Munde, "My Year as Interim: Six Things I Learned for Free," 61(5) College \& Research Libraries News 416-420 (2000). After noting that at her own university the interim "may not apply for that position," Munde further opines that "I doubt this arrangement is the norm." Id. at 416. See also Kobulnicky, at 24 ("There was no consensus among those whom I interviewed on the desirability of the acting director being a candidate for the directorship.").
} 
than is generally the case. ${ }^{9}$ There are, however, sound reasons why this strategy is rare and may be more characteristic of the outside interim, as is the case here. ${ }^{10}$ While some interims believe their terms should be fairly aggressive steps forward, ${ }^{11}$ Euster reasonably argues that, just as she, as incoming Director, would "tend not to make many drastic changes in the first six to twelve months; since most acting directors serve somewhere in that time frame, I'd expect them to make few permanent systemic changes." 12 The most defensible instance of the practice would probably be when plans for the changes were already in place when the interim took office, rather than being one of her own devising.

Finally, the situation described by Pat of having the functional duties of the interim while another holds the title finds no parallel in the literature. This may be a result of the fact that - unlike the deep hierarchies typical of university libraries, the source of most of this writing - law libraries are usually small shops. Regardless of titles, there are simply fewer options for who does what tasks.

\section{The Decision to Apply}

Despite the lack of formal status as interim, I endeavored to prove myself in ways that would be important should I become Director. For example, I taught Advanced Legal Research during that summer session, a course usually taught by the Director. Staff librarians normally gained teaching experience only by offering individual research classes in courses taught by other faculty members. I found the experience very rewarding. It made me feel even more connected to our student body as former students stopped and mentioned how they were using their research skills in their classes.

The successes we had in the library during this time period led me to feel I had made the correct decision to apply for the open position. Yes, there were risks involved. When you apply for an in-house job, you are really putting yourself out there and being closely evaluated and critiqued by your colleagues. You have to have a thick skin to be comfortable enough to deal with this scrutiny over an extend process. In our case, the position became available on July 1st and was not filled until late November.

Once the job posting was posted on the AALL listserv (sometime in early June, I believe), I spent about three or four weeks deciding whether to submit my application. The job posting noted that applicants would be interviewed at AALL's annual meeting, so I knew I had some time to decide. I was not attending AALL that year, but was aware of the fact

\footnotetext{
${ }^{9}$ See, e.g., Euster and Solomon at 139 ("One of the things I have always hoped for (maybe fantasized about is a better word here) from an acting director is to have made some of the really unpopular decisions, thus protecting my honeymoon period a little.").

${ }^{10}$ But see Leslie R. Morris, "The Case for an Outside Interim Director," 35(6) American Libraries 53-54 (2004) ("The Outside Interim, because she has no ties to the current staff, can make needed, even though unpleasant, changes in staff and procedures.").

${ }^{11}$ E.g., Lynn Chmelir, "Here Today, Gone Tomorrow: Observations of an Interim Academic Library Director," 18(1) OLA Quarterly 6-7 (2012) ("The interim period must be a time for progress....").

${ }^{12}$ Euster and Solomon at 142-143.
} 
that local applicants in whom the committee was interested would be interviewed on campus after the conference.

Why did it take me several weeks to submit my application? I was weighing the advantages against the disadvantages.

One concern was that the primary advantage I felt as an insider could also serve as a major hindrance. My deep familiarity with the library had been earned by long years working many positions in the organization and acquiring different skills and experiences. I'd been at WNE since 1995, and my long tenure surely demonstrated my commitment to the school and to its success. But this depth was earned at the cost of exposure to different libraries. Although I did have prior experience at other libraries (seven years at private law firms, two years at an academic library), my academic law library experience had been all at this one institution. Depending on the viewpoint, then, my strongest qualification could be my greatest weakness.

There were, of course, other things to consider. Many of the faculty and the entire library staff knew me in my current capacity. Some may have trouble viewing me in a new role, and especially as "the boss." I also realized that, as an inside candidate, I would likely have very little bargaining power in negotiating salary, benefits, and increased library support. The assumption would like be that I would prefer to accept this position under any offered terms than walk away, which obviously gives the school a clear advantage. I realized I could live that that. They were right: I did want the job!

The factor that weighed most heavily, though, was the thought that in the end I may not receive the job. Would I be comfortable staying in my position as Associate Director if I did not receive the promotion? I love working at our Library and our law school. I realized that I could stay even in that circumstance.

I viewed the School of Law as my home. I would not choose to leave it. I've worked for three previous Directors and have observed various management styles and yes, you can take something positive from watching all types of management skills by learning what does and doesn't work! In any case, after the number of years here observing management and managing myself, the thought of adjusting to yet another manager was a bit daunting. I knew though that if need be, I could adjust.

Of course, this decision - whether to stay pending an unfavorable selection outcomewas not entirely in my own hands. Perhaps the new Director would not be comfortable working with me, given that my desire to assume the role was now public knowledge. Or maybe the person chosen would want an Associate of her own choosing. In either case I would find myself in a difficult situation.

There would be a heavy price to pay, however, if I decided not to apply as well. I would then have little control over the future of the library for which I cared deeply.

Participating in the job selection process were I not a candidate would give me some 
input into the hiring process and selection of a candidate, but the reality is that my one voice would not be strong enough to have much of an impact.

The list of advantages favoring my applying was perhaps obvious. I knew the law school and the library staff, so I would not require much time to get up to speed were I to become Director. By comparison, an external hire would need to spend a substantial amount of time laying the foundation of new leadership, communicating his vision, plans, direction, and strategies. That was one thing I could cross off my to-do list: I did not have to read the organizational and institutional climate.

On balance, there were risks if I didn't apply, and these were risks I weighed more heavily than those I ran if I did apply. In the end, perhaps, I owed it to the school (and even to myself), to offer myself as a candidate. After weighing the pros and cons, I decided to move forward on my application. I was not first in line, but neither was I last. I know that some applications were received prior to mine, and many were received afterwards.

This resolve did not mean there weren't difficult days during which I questioned my decision or when I didn't think about withdrawing my application. It was a big help to feel the support of many of our library staff members. I felt encouraged by this and it buoyed me on those difficult days.

The balancing exercise that Pat attempts is far from a hard science. The same facts going into such calculations will be weighted differently according to whether one is the insider or the outsider. For example, outside candidates know, for example, that whenever inside candidates are in the pool, employers tend to prefer the insiders. ${ }^{13}$ Reasons for this favor are not mysterious. "An inside candidate has the advantage of being a known quantity and will have an established track record with which the dean is familiar."14

Along the same lines, at least in the business environment "external hires will initially perform worse than workers entering the job from inside the firm and have higher exit rates.... [W] orkers promoted into jobs have significantly better performance for the first two years than workers hired into similar jobs and lower rates of voluntary and involuntary exit." 15

These examples all favor the inside candidate. For these dubious outcomes organizations can expect to pay outsiders "around 18 percent more than the

\footnotetext{
${ }^{13}$ Rick M. Gardner, The Fate of External Candidates When Inside Candidates Vie for Administrative Positions in Higher Education, 67 Psychological Reports 1347 (1990) ("Results indicated a strong preference for hiring inside candidates for most administrative positions, with the exception of the presidency.").

${ }^{14}$ Francis X. Norton, Jr., Twelve Directors: A Quick View of New Academic Library Directors, 15(3) AALL Spectrum 10, 11 (December 2010).

${ }^{15}$ Matthew Bidwell, Paying More to Get Less: The Effects of External Hiring versus Internal Mobility," 56 Administrative Science Quarterly 369, 369 (2011).
} 
promoted workers." 16 In other words, outside candidates often perform worse, but cost more, which again favors the inside candidate. Although similar empirical findings are lacking for the library context, these results echo the informal advice from its eminences: As "an insider you will have very little leverage in negotiating with the law school for salary, benefits, and library support. The law school will always assume that you would rather have the job than not - this fact gives it the upper hand." ${ }^{, 17}$ Pat therefore demonstrates considerable realism in expecting to earn less as an internal hire than would be offered to a successful outside candidate for this same position.

The risks for an external candidate can lead some to decline to invest in a search process if a viable internal candidate is being considered. ${ }^{18}$ This may be especially true if that person currently serves as the library's interim director who will be able to speak with far greater familiarity about the needs and possibilities of the library than the outside candidate can muster. ${ }^{19}$ Again, however, there are tradeoffs. While the internal applicant may feel that extended interim experience heightens her appeal to the search committee, Kobulnicky concludes that the "longer your period of acting the worse your chance at being the director.",20

Outsiders will not always know whether an internal candidate has applied, or knowing may nonetheless commit to the grueling application process for a variety of reasons both professional and personal. Factoring into the decision may be the library's most recent experiences. If the organization has gone through a troubled period, or even one of pleasant but unproductive stagnation, an outsider with fresh ideas and new energy may be especially enticing to a committee; on the other hand, where the library has achieved a recognized level of excellence the preference may be for the insider who will continue this proven course. Such evaluations can differ greatly, and the insider should not presume to have read the signs correctly: "The perspectives of internal candidates and of search committees are seldom similar.",21

In the end, Pat identifies what the literature suggests is indeed the most explosive consideration: How will she handle the possibility that another will be chosen over her? Some writers are skeptical of an easy return to the fold after having

\footnotetext{
${ }^{16}$ Bidwell at 369.

${ }^{17}$ Penny A. Hazelton, Rebuilding the Profession: Recommendations for Librarians Interested in Becoming Academic Law Library Directors: Job Experience, 99 Law Library Journal 122, 124 (2007).

${ }^{18}$ Jean Dowdall, Does the Internal Candidate Have the Edge?, The Chronicle of Higher Education, April 7, 2000, at http://chronicle.com/article/Does-the-Internal-Candidate/46277/ ("If outsiders perceive that there are internal candidates who are highly likely to get the job, they are far less likely to become candidates themselves.").

${ }^{19}$ Interestingly, this does not appear to hold true in the case of Pat's search. One outside candidate for her position reported that knowing of the existence of an inside candidate did not influence his decision to apply. He suggested, however, that the fact that he did not specifically know Pat at the time may have had an impact. Had a prior relationship existed, he would have been inclined to avoid a direct contest for the opening.

${ }^{20}$ Kobulnicky, p. 9.

${ }^{21}$ Kobulnicky, p. 18.
} 
made a claim on the throne. ${ }^{22}$ There are two personalities to be considered here: the candidate, who may feel insecure and unappreciated, and the new director, who faces assuming a new position, fraught with difficulty in even the most ideal circumstances, under the judging and challenging eye of a reject applicant. "It is the exceptional director who can make a former leader of the organization an effective subordinate." ${ }^{23}$ The internal candidate should have a realistic understanding of how she might feel should her nomination fail. Whether to begin the process of leaving by applying for other directorships, or to stay as a fully supportive subordinate to the person selected, is a decision to be made before, and not after the application process. ${ }^{24}$

\section{The Interview Process}

It did feel a bit strange to submit a formal letter of application to the Chair of the Search Committee. I had received three promotions at WNE since I began, none of which I had applied for, so I was, let's just say, "unfamiliar" with this situation. I drafted my letter, sent it off via my personal email account in early July, and received an acknowledgement of receipt. The reply mentioned that the Committee would narrow down applications to several candidates, in addition to me, with whom they would conduct initial screening interviews. Based on these interviews they would select a smaller pool of candidates whose applications they would present to the full faculty to be invited for site interviews. Then the waiting began.

The Hiring Committee consisted of four faculty members and one librarian. The Chair of the Committee and the librarian went to AALL to interview candidates. As I was unable to attend AALL that summer, I did not see the process as I might have had I been an attendee. In any case, after AALL, sometime in August, on-campus interviews with candidates were arranged.

Several candidates arrived on campus for day long interviews. As an inside candidate my interview process was conducted the same as the other candidates, including the "length and scope of interview and review" by the search committee.

I found out that my interview would take place in September (third of four), and it would include a job talk. I had a scheduled vacation shortly after getting this schedule, so I was able to prepare for the presentation while relaxing on Cape Cod. Topics were not assigned. I chose to speak on my vision of the future of our School of Law Library, a talk that proved easy to put together.

Going through the interview process and talking about my experience and what issues I foresaw for the library proved to be a surprisingly enjoyable process. I met individually with some faculty members, in groups with others, and finally with the Committee as a

\footnotetext{
${ }^{22}$ Kobulnicky, p. 23 ("Declaring one's intention to be the leader makes it hard, and in some situations impossible, to return to a more collegial position in the organization.").

${ }^{23}$ Kobulnicky, p. 17.

${ }^{24}$ See Hazelton, p. 124 ("If you cannot face the possibility of failure, don't put yourself in the running.").
} 
whole. The job talk gave me an opportunity to talk about what we were currently doing in the library and what plans I saw for our future. I felt I definitely had the advantage over outside candidates in being able to talk about these issues with specificity. I knew exactly where we were in regards to important issues, such as rightsizing the library's resources, budget issues, planning for multiple uses for existing library space, reexamining the role of support staff, dealing with current unfilled positions, in short the full range of library matters.

Most importantly I discussed more open communication between the library and faculty and administrators, and among the entire library staff. I explained that this was a priority of mine and something that clearly needed rectifying. It was rare to have the faculty's attention to discuss broad library issues, so that in itself was worth putting myself out there in applying for the position.

As the weeks passed, I found that it was not easy to be the in-house candidate and see a variety of candidates come in to interview for the position I wanted. I was naturally excluded from the others' interviews in which all the other staff were participating. I could only pretend to ignore the talk going on among staff members after a candidate had visited. They chatted about whether they had done a good job, and if the staff could see them as a good fit with the library. This talk proved awkward as I would walk around a corner into a conversation that quickly quieted down when they noticed me.

The selection process to find a new library director can be a strategic minefield for any candidate. Unsurprisingly, prior experiences with the challenging demands give a benefit. ${ }^{25}$ This fact should be one further consideration in the decision to apply at all. Even if chances are not favorable to win this specific position, learning what will be expected can give a needed edge when competing later for that perfect opportunity.

Easily forgotten by both candidates and search committees is that there is no such thing as a good director in the abstract sense; there is only a director good for that institution. Just as libraries are themselves particular to their settings, ${ }^{26}$ likewise directors must fit into that environment. A person who would thrive in one library may be a disappointment in another. Finding that fit is a chancy business, but in the end perhaps the most important. The committee's comfort level over bringing the two together may encourage them to overlook weaknesses in other, more remediable areas. ${ }^{27}$

Several special issues for the internal candidate at this phase can be mentioned. During Pat's search, the initial screening of candidates occurred as face-to-face

\footnotetext{
25 Peter Hernon, "Becoming a University Library Director," 33 Library \& Information Science Research 276-283, 282 (2011) 282 ("those for whom this was not their first directorship benefited from having gone through the search experience before.")

${ }^{26}$ James M. Donovan, "A Library is Not the Books: An Ethical Obstacle to the Digital Library," 10 Journal of Information, Communication \& Ethics in Society 93-106 (2012).

${ }^{27}$ Hernon, p. 280 ("At some point, a gut instinct guides the decision.").
} 
meetings at the annual AALL convention. Another common approach is to conduct telephone or video conferencing interviews. On the one hand, it might seem ridiculous to Skype or phone someone sitting down the hall; on the other, given the difference of communication media, ${ }^{28}$ this difference can create an uneven playing field. To our knowledge no standard practice has emerged on this question, but it merits discussion within the committee.

Another potentially delicate matter touches on the suggestions an internal candidate makes regarding institutional improvements. An obvious question that can be raised, that would not be asked of an outside candidate, asks something along the line that, given that the candidate was currently part of the organization, why weren't these things happening already? This may be read as either an implied criticism of the prior administration - rarely a good thing, especially during an interview - or a concession that one has not been doing all that could have been done. Barden (2008) raises these and similarly pertinent issues in what is perhaps one of the most useful readings for any inside candidate. ${ }^{29} \mathrm{An}$ appropriate response will depend on the specific suggestion being offered, but the candidate should be prepared to address such probes.

The sheer mechanics of the on-site interview offers its own array of issues, as Pat noticed during her own process. At this level a serious internal candidate invariably sits highly in the library hierarchy. Pat did not speak with the other candidates, a practice that arguably raises problems of its own when the Associate Director does not speak with a candidate for Director. ${ }^{30}$ Alternatively, the second author, during one interview for a director's position, was scheduled to speak with the associate director who was also a candidate. She was forthright about the conflict of interest, dispelling any tensions, but the choice raises an interesting question for present purposes. Had I not spoken with her, my exposure to important features of the library's environment would have been significantly incomplete; yet, to give one candidate the opportunity to interview a competitor and presumably voice an opinion - appears to give the local person an undue and arguably unethical advantage. ${ }^{31}$

\footnotetext{
${ }^{28}$ E.g., Susan G. Straus, Jeffrey A. Miles, \& Laurie L. Levesque, “The Effects of Videoconference, Telephone, and Face-to-Face Media on Interviewer and Applicant Judgments in Employment Interviews," 27 Journal of Management 363-381 (2001); Derek S. Chapman, Krista L. Uggersley, \& Jane Webster, “Applicant Reactions to Face-to-Face and Technology-Mediated Interviews: A Field Investigation,” 88 Journal of Applied Psychology 944-953 (2003).

${ }^{29}$ Dennis M. Barden, "The Internal-Candidate Syndrome”, Chronicle of Higher Education, Vol. 54 No. 35 , p. C2.

${ }^{30}$ E.g., Kobulnicky, p. 16:

One of the most difficult periods for the acting director who is a candidate is the time when other candidates are on campus.... The question of whether it is proper for the acting director/candidate to meet with the other candidates to appraise them of local issues and to answer necessary questions often seems to search committees to be improper and unequal. However, when the acting director is removed from the search process he or she is also kept at a distance from the concerns of the rest of the staff and isolated from the very system he or she is charged to lead.

${ }^{31}$ In the end, neither of us got the position.
} 


\section{Taking Control}

I was happy to be offered the position as Library Director in November. The support of the library staff was very encouraging; they had a party for me in the library with cake and champagne. It was heartening to receive many well wishes from other administrators and faculty also. One thing I knew right away was that I did not want to have an Associate Director. We already were top heavy in administrative positions and I thought it was important to continue to be a "doer" in the library.

One of the many positive things about being an internal candidate is that I was able to quickly move into my new position without a transition period. There was no period of having to test the waters, and get to know staff, to have to be careful of making too many changes at once.

I had been told upon hiring that one of the first things I needed to accomplish was a strategic plan. Luckily, I had been talking with the librarians over the past several months about where we all wanted to be headed. Because I had never written a strategic plan, one of the staff members searched for other law school examples for me to review. After reviewing the literature, I was able to quickly complete a draft for the librarians' perusal and discussion. We were all on the same page, and agreed on nine identified goals.

I worked to garner more support for the law school by offering assistance to the undergraduate programs. I arranged meetings with the University's Chairs of Departments that offer "Law \&" courses to discuss our librarians' availability for legal research instruction. We now offer these classes here at the law school. The meetings not only introduce undergraduates to the resources available to them and thereby assist our undergraduate faculty in their course instruction, but perhaps even interest some of our own undergrads in applying to our law school after graduation.

When I look back over the past year many other accomplishments come to mind-many of which I doubt would have been attainable in such a short time by an external candidate. I was able to hit the ground running.

Having won the job, the chosen Director must act quickly to assure success. Failing to "build momentum" during the transition phase can negatively impact the long-term success of a new manager. ${ }^{32}$ The first ninety days can be especially critical.

Whatever one's path to the Director's office, they probably suffer under a false impression concerning their preparedness for this step up. "Everyone on your staff thinks they know what it's like to be the director. They're all wrong. We have no clue what it's really like until it happens to us."33 Invoking a particularly vivid

\footnotetext{
${ }^{32}$ Michael Watkins, "Taking Charge," 36 Government Executive 76-77 (2004).

${ }^{33}$ Lynne Olver, "So You're the New Director? Twelve Points to Help You Survive the First Year," 50(2)

Public Libraries 6-7, 7 (2011).
} 
analogy, when asked how well his earlier positions had prepared him to take on his new duties, one first-time director replied, "A little less than babysitting prepared me to be a parent!"34

In light of this need to succeed quickly in a context for which most are poorly prepared, the internal candidate arguably has a clear advantage. External hires must walk a fine line between doing too much, too soon, and doing too little:

For a new chief librarian in the encounter and adjustment stages, one decision will be what actions to take during the "honeymoon period" of the new tenure. To act too soon could be precipitous and mean that one has not had the opportunity to collect all the appropriate background. To linger too long, however, could signal either lack of decisiveness or that one is offering only custodial management rather than leadership. ${ }^{35}$

Given that taking such steps should be a function of information about the "appropriate background," those hired from within the organization will be able to move on this agenda more quickly than those from outside, who must take longer to adequately survey the present lay of the land. Pat relates how her intimate knowledge of the library she was chosen to direct allowed her to take immediate actions whose successes put her administration on a strong and positive track during those vulnerable early months.

That tangible benefit appears without considering other variables. An internal candidate, for example, can step into the position almost immediately after selection. An outside selection, however, must first give notice at her present position and most likely relocate before being available for duty. This process prolongs the interim period during which the library lingers in limbo, risking the entrainment of an attitude of inaction among the staff.

While these observations reflect primarily on the impact of the transition on the organization, we should also comment on a frequently unnoticed outcome on the Director. Several writers mention being surprised by the social isolation experienced by many directors: "New library directors quickly realize that their peer group has drastically changed from inside the library to the campus level.

\footnotetext{
${ }^{34}$ Brian Soneda, "News Flash! First-time Directors Spill Their Guts!" 21(3) ALKI: The Washington Library Association Journal 16-18, 16 (2005). For overviews about what it is that directors actually do, see Peter Hernon, Ronald R. Powell, \& Arthur P. Young, "Academic Library Directors: What Do They Do?" 65 College \& Research Libraries 538-563 (2004); Carol Bredemeyer, "What Do Directors Do?" 96 Law Library Journal 317-331 (2004).

${ }^{35}$ Catherine J. Matthews, Becoming a Chief Librarian: An Analysis of Transition Stages in Academic Library Leadership, 50 Library Trends 578-602, 591 (2002); see also Steven H. Appelbaum, \& Miguel Valero, "The Crucial First Three Months: An Analysis of Leadership Transition Traps and Successes," 11 Journal of American Academy of Business 1-8 (2007) (49\% of survey respondents identified as the three most important mistakes in the first ninety days as not taking time to understand the environment before making changes, including not building relationships, and presuming to arrive with 'The Answer'.")
} 
Deans and administrators, along with director colleagues from other institutions, are the new peer group moving forward."36

This negative emotional aspect of becoming Director may be even more profound for internal candidates, who had relationships with staff that may now need to be redefined. Friends are now subordinates who must be evaluated and perhaps criticized. Whereas interactions were once free and natural, now they can be evasive and vague as the Director - privy to confidential administrative information - must now invest energy to avoid disclosing too much. Remaining too familiar with some can make others jealous, leading to suspicious of favoritism and lack of objectivity. Pat does not address this need to increase distance from her staff. Future studies of the experience of being director, however, should not only include this psychological dimension, but should also seek to investigate whether it arises differentially between external and internal hires.

\section{Final Thoughts}

So, now after one year has passed, how do I feel about having taken on this new role in the library? As an internal candidate who succeeded in becoming Director, there was a tangible shift in focus from the relentless day-to-day routine that I worked under as Associate Director, to the need to understand and respond to the complex problems facing the law school. The position requires both management and leadership. Being director has few mileposts to measure performance. Instead, the work is open-ended and at times seems unrelenting.

Even with increased stress and demands on time, the transition has been a rewarding experience. Promoting from within has allowed me to move forward quickly with new initiatives. Because there was no waiting period to grow accustomed to the organization, staff, and issues, I was able to feel gratification in completing significant projects within a short time period. The immediate positive feedback bolstered my confidence to move rapidly and confidently into less familiar territory at a pace unlikely to be found in even the most able of new hires arriving from the outside.

A recent review of performance effectiveness of library administrators shows clearly the major empirical approaches have not encompassed the variable that we argue to be relevant to the fuller understanding of how specific directorships unfold. ${ }^{37}$ Absent from the published literature is any extended consideration of how having risen from the ranks of the library one is now tapped to lead, or

\footnotetext{
${ }^{36}$ Dewey, at 140 .

${ }^{37}$ Jody Condit Fagan, The Effectiveness of Academic Library Deans and Directors: A Literature Review, 26 Library Leadership \& Management 1-19, 5 (2012) ("Since 2005, empirical studies in the library literature have focused on only five research areas within the topic of leadership effectiveness: the role of emotional intelligence, the attitudes of presidents and provosts toward the university library, the perceptions of Generation X librarians, evidence-based library management, and deans' use and awareness of the ACRL standards for Libraries in Higher Education.").
} 
coming in from an outside institution, impacts both how one approaches the first months, and determines the long-range effectiveness of the appointment.

Pat's personal account demonstrates clearly how the outsider/insider difference influences every facet of the new position, from how the person is selected to the ease and even ultimate success of the transition. 